\title{
N Domain
}

National Cancer Institute

\section{Source}

National Cancer Institute. N Domain. NCI Thesaurus. Code C25902.

N Domain is one of the seven predicted immunoglobulin-like domains that members of the CEA family protein have. It is extremely hydrophobic. (From OMIM and NCI) 